\title{
Psychosocial Adjustment of Healthcare Professionals During the COVID-19 Pandemic: Resident Doctors, Nurses, and Caregivers Need Extra Attention
}

\section{Sağlık Çalışanlarının COVID-19 Pandemi Sürecindeki Psikososyal Uyumları: Asistan Doktorlar, Hemşireler ve Hasta Bakıcıların Ekstra İlgiye İhtiyacı Var}

\author{
(1) Fatma Akyüz Karacan'1, (D) Semra Yılmaz², (1) İsmet Kırpınar ${ }^{1}$ \\ ${ }^{1}$ Bezmialem Vakıf University Faculty of Medicine, Department of Psychiatry, Istanbul, Turkey \\ 2University of Health Science Turkey, Bakırköy Dr. Sadi Konuk Training and Research Hospital, Clinic of Child Psychiatry Policlinic, Istanbul, Turkey
}

\begin{abstract}
Objective: This study aimed to examine the psychosocial adjustment and its association with occupation, hospital unit, social support, and Coronavirus disease-2019 (COVID-19) attitude in the healthcare professionals during the COVID-19 pandemic.

Methods: This descriptive cross-sectional study was conducted in two pandemic hospitals with a total of 557 participants, which included healthcare professionals of all occupations and all hospital units. Socio-demographic characteristics and COVID-19 attitude and knowledge were evaluated with the data form. The hospital anxiety-depression scale (HADS), beck hopelessness scale (BHS), maslach burnout inventory (MBI), fear of COVID-19 scale (FC-19S), and multidimensional scale of perceived social support (MSPSS) were used to assess psychosocial adjustment and social support.

Results: Females had higher levels of HADS-anxiety, FC-19S, MBI-emotional exhaustion, and MSPSS-friend and MSPSS-significant other subscales $(p<0.05)$. Scores of BHS (highest in resident doctors and caregivers), HADS-anxiety (highest in resident doctor), HADS-depression (highest in caregivers), and MBI-emotional exhaustion and MBI-depersonalization (highest in the resident doctors) were seen to differ with occupation $(p<0.05)$. Scores of HADS-Depression, FC-19S, and MBI-emotional exhaustion were higher in participants working at the intensive care unit $(p<0.05)$. Having COVID-19 polymerase chain reaction examination history was related to higher scores of BHS, HADS-anxiety, HADSdepression, and FC-19S, and lower scores of MSPSS scores $(p<0.05)$. MSPSS scores were negatively correlated with HADS-anxiety, HADSdepression, MBI-emotional exhaustion, and MBI-depersonalization scores.
\end{abstract}

Conclusion: Results indicate that gender, occupation, and hospital unit influence the psychosocial adjustment of healthcare professionals. Moreover, social support, COVID-19 attitude, and psychosocial adjustment are interrelated with each other.

Keywords: Psychosocial adjustment, COVID-19, healthcare professionals, social support, COVID-19 attitude

\section{öz}

Amaç: Bu çalışmada Koronavirüs hastalığı-2019 (COVID-19) pandemi sürecinde sağlık çalışanlarının psikososyal uyumu ile meslek, hastane çalışma birimi, sosyal destek ve COVID-19 tutumu arasındaki ilişkinin incelemesini amaçladık.

Gereç ve Yöntem: Kesitsel ve tanımlayıcı olan bu çalışma 2 pandemi hastanesinde yürütüldü. Katılımcılar, tüm meslek guruplarından ve tüm hastane çalışma birimlerinden alınan toplam 557 sağlık çalışanı idi. Sosyo-demografik özellikler ile COVID-19 tutum ve bilgi düzeyini değerlendirmek için araştırmacılar tarafından geliştirilmiş veri formu kullanıldı. Psikososyal uyum ve sosyal desteğin değerlendirilmesi için; Hastane anksiyete-depresyon ölçeği (HADÖ), beck umutsuzluk ölçeği (BUÖ), maslach tükenmişlik ölçeği (MTÖ), COVID-19 korkusu ölçeği ve çok boyutlu algılanan sosyal destek ölçeği (ÇBASDÖ) kullanıldı.

Bulgular: HADÖ-anksiyete, COVID-19 korkusu ölçeği, MTÖ-duygusal tükenme, ÇBASDÖ-arkadaş ve özel arkadaş alt ölçek puanları kadınlarda erkeklere göre daha yüksekti $(p<0,05)$. BUÖ (en yüksek asistan doktorlarda ve hasta bakııılarda), HADÖ-anksiyete (asistan doktorlarda en yüksek), HADÖ-depresyon (hasta bakıcılarda en yüksek), MTÖ-duygusal tükenme ve duyarsızlaşma (asistan doktorlarda en yüksek) puanları olarak görüldü ve mesleğe göre farklılık göstermekteydi $(p<0,05)$. COVID-19 polimeraz zincirleme reaksiyonu testi yaptırmayanlarla kıyaslandıklarında,

Address for Correspondence: Fatma Akyüz Karacan, Bezmialem Vakıf University Faculty of Medicine, Department of Psychiatry, Istanbul, Turkey

Phone: +90 2124531700 E-mail: ftmakyuz@yahoo.com.tr ORCID ID: orcid.org/0000-0001-6166-9355

Cite as: Akyüz Karacan F, Yılmaz S, Kırpınar I. Psychosocial Adjustment of Healthcare Professionals During the COVID-19 Pandemic: Resident Doctors, Nurses, and Caregivers Need Extra Attention. Med J Bakirkoy 2021;17:375-385

Received: 13.09 .2021

Accepted: 25.10.2021 
yaptıranlarda BUÖ, HADÖ-anksiyete, HADÖ-depresyon, COVID-19 korkusu puanları daha yüksek ve ÇBASDÖ puanları daha düşüktü (p<0,05). ÇBASDÖ puanları ile HADÖ-anksiyete, HADÖ-depresyon, MTÖ-duygusal tükenme ve MTÖ-duyarsızlaşma puanları arasında negatif korelasyon vardı.

Sonuç: Çalışmamızın sonuçları sağlık çalışanlarının psikososyal uyumunun cinsiyet, meslek ve hastane çalışma biriminden etkilendiğini göstermiştir. Ayrıca sosyal destek, COVID-19 tutumu ve psikososyal uyum birbiriyle ilişkilidir.

Anahtar Kelimeler: Psikososyal uyum, COVID-19, sağlık çalışanları, sosyal destek, COVID-19 tutum

\section{INTRODUCTION}

Pandemic refers to the occurrence of a specific disease worldwide or over a very wide area that crosses international boundaries, which usually affects a large number of people (1). Coronavirus disease-2019 (COVID-19) was first seen in China in December 2019, which quickly became a worldwide threat, and was declared a pandemic by the World Health Organization in March 2020. The first case in Turkey was reported on March 11, 2020, and as of April 30,2021 , the total number of reported cases was 4,820,591 with 40,131 deaths (2). It has been approximately 1.5 years since the pandemic started. Important progress has been achieved in its treatment during this period; however, the exact treatment is yet to be found.

Isolation is the most effective method in the primary treatment of infectious diseases (3). Therefore, together with face masks and hand hygiene, it has been the main measure that was used to prevent the spread of the disease during the COVID-19 pandemic (4). Since the disease has a very high transmission rate and many people showed to be asymptomatic carriers of the virus, the governments had to enforce strict social isolation rules that must be followed by all people, regardless of their health status. Similar to many countries, several precautions were taken for social isolation in Turkey since the pandemic began. The national and international transportations were restricted and even prohibited, and shopping malls and entertainment centers were closed and education was switched to online applications. The time for these restrictions and regulations to return to the past normal is still unknown. Pandemics can cause social changes, regulations, and restrictions, along with many uncertainties. Moreover, everyone is affected by these changes in their daily lives and work habits, and problems in food, shelter, and basic needs arise, aside from the direct effect of the disease during this pandemic. All these situations may lead to increased psychosocial distress in individuals.

Studies have demonstrated that public mental health is adversely affected during the COVID-19 pandemic $(5,6)$. Healthcare professionals, occupying the frontline during pandemics, have increased risk for mental health besides the increased risk of contacting viral infection (7-9). Excessive workload, unpreparedness, and emotional distress are the reported reasons for increased psychological problems in the health professionals (e.g., fear of infection and family concerns) $(4,8)$. Compared to previous ones, the COVID-19 pandemic is more challenging because of some specific features of the virus, such as high contagiousness, a rather low level of knowledge on its course and long-term consequences, and a lack of established treatments or vaccines (10). Moreover, this is an unprecedented scenario for most hospitals worldwide, which is accompanied by great challenges in various aspects of health care, such as hygiene concepts, sufficient protective measures and equipment, and competence and capacity of the intensive care unit (ICU). Furthermore, many healthcare professionals have been isolated, not only from their social environment but also from their families unlike other people because of their higher risk of contacting the virus and becoming a carrier and their exposure to the illness and loss of their counterparts.

Studies demonstrated that healthcare professionals have higher levels of anxiety and hopelessness compared to the community samples during the COVID-19 pandemic (4). Symptoms of anxiety, depression, stress, and burnout are more common in frontline healthcare professionals, who are involved in the diagnosis, treatment, and care of patients with COVID-19, compared to those who do not work on the frontline $(11,12)$. Gender and occupation showed the importance for their psychological well-being; fear of COVID-19 is higher in females and nurses (13). Social support is associated with a positive COVID-19 attitude in health professionals (14). Social support was associated with burnout in nurses who are at the center of this pandemic (15). Many studies were conducted on healthcare professionals; however, they were carried out especially in the acute and shock phase of the pandemic and examined only certain symptoms by considering limited parameters.

Therefore, this study aimed to examine the psychological adjustment and its association with COVID-19 attitude and social support among the frontline healthcare professionals during the COVID-19 pandemic in Turkey. The study was conducted 8 weeks after the emergence of the pandemic 
to eliminate the acute stress effects. Out first hypothesis is that anxiety, depression, burnout, and hopelessness would be higher in healthcare professionals who had more contact with patients with COVID-19. The second is that higher social support and a positive attitude towards COVID-19 would be associated with better psychological adaptation.

\section{METHODS}

\section{Study Design and Participants}

This descriptive cross-sectional study was conducted from May 1, 2020, to June 30, 2020, in two state hospitals that were located on the European side of Istanbul. These two hospitals share the same staff and serve most of the COVID-19 cases on the European side of Istanbul since the beginning of the COVID-19 pandemic. The total number of hospital beds of these hospitals is $1,618(1,008+610)$ and the total intensive care beds are $513(408+105)$. Assuming a pooled standard deviation of 5 units, the study would require a sample size of 44 for each group (i.e., a total sample size of 88, assuming equal group sizes) to achieve a power of $80 \%$ and a significance level of $5 \%$ (two-sided) and detect a true difference in means between the test and the reference group of 3 units. Inclusion criteria of the study include healthcare professionals who are 18-65 years old, with voluntary participation in the study and are capable of filling up the forms. Healthcare professionals were asked about their medical and psychiatric history, and those with a psychiatric or chronic illness were excluded from the study. Participants were divided into 6 subgroups according to their occupations: specialist doctors, resident doctors, nurses, caregivers, medical secretaries, and security guards. All participants filled out the data form, hospital anxietydepression scale (HADS), beck hopelessness scale (BHS), maslach burnout scale, fear of COVID-19 scale (FC-19S), and multidimensional scale of perceived social support (MSPSS).

\section{Measurements Tools}

Data form: This form was developed by the researchers to gather information related to sociodemographic information (e.g., sex, age, family, and occupation) and COVID-19 attitudes and knowledge of participants. Questions related to COVID-19 attitudes and knowledge were as follows: 1) Are you following new literature knowledge on COVID-19 disease? (answers were: 1. yes and 2. no); 2) Did you have laboratory, radiological, and COVID-19 polymerase chain reaction (PCR) tests until today? (answers were: 1. yes and 2. no); 3) Do you think the pandemic will end (answers were: 1. yes and 2. no); 4. Do you think your institution provides adequate protection methods for COVID-19? (answers were: 1. yes, 2. no, and 3. partially provided).

HADS: This is a 4-point scale consisting of two subscales, HADS-anxiety (rating the anxiety level) and HADSdepression (rating the depression level). Each subscale consists of seven items. Participants answer each item thinking of their emotions and/or behavior during the past week. Higher scores indicate higher levels of anxiety and depression (16). The Turkish validity and reliability study was done by Aydemir et al. (17).

BHS: This is a 20 item self-assessment instrument to measure hopelessness (18). The participant is asked to evaluate each of the 20 statements and decide whether the statement describes his/her attitude in the previous week. The scale has nine inverse items to prevent acquiescence. The total score range from 0 to 20, indicating the number of items endorsed in the hopeless direction. Its Turkish validity and reliability were done by Durak and Palabıyıkoğlu (19).

Maslach Burnout Inventory (MBI): The $\mathrm{MBI}$ is a 7-point Likert-type scale, consisting of a 22-item rating of the three dimensions of burnouts, namely emotional exhaustion, depersonalization, and personal accomplishment (20). Its Turkish validity and reliability study was done by Ergin (21).

FC-19S: It was developed by Ahorsu et al. (22) to measure the fear level related to COVID-19. The 5-point Likert type scale has a single factor structure and consists of seven items ( $1=$ strongly disagree; $5=$ strongly agree) (22). Its Turkish validity and reliability study was done by Ladikli et al. (23).

MSPSS: This Likert-type scale was developed by Zimet et al. (24) which evaluates the adequacy of social support received from three different sources: family (MDSPSSFamily), friends (MDSPSS-Friends), and significant others (MDSPSS-significant others). It has a total of 12 items. Its Turkish validity and reliability study was done by Eker et al. (25).

\section{Ethical Approval}

Written and verbal consent of each participant was obtained. This study was conducted according to the provisions of the Declaration of Helsinki in 1995. Approval was obtained from the ethics committee of the same hospital with the University of Health Sciences Turkey, Bakirköy Dr. Sadi Konuk Training and Research Hospital (protocol number: 2020-157).

\section{Statistical Analysis}

The Number Cruncher Statistical System program was used for statistical analysis. Descriptive statistical methods (mean, standard deviation, median, frequency, percentage, 
minimum, and maximum) were used to evaluate the study data. The suitability of quantitative data to normal distribution was tested by the Shapiro-Wilk test and graphical analysis. The Student's t-test was used to compare normally distributed quantitative variables between two groups, and the Mann-Whitney $U$ test was used to compare quantitative variables that did not show normal distribution between two groups. The One-Way analysis of variance and Bonferroni corrected binary evaluations were used to compare more than two groups of quantitative variables with normal distribution. The Kruskal-Wallis and DunnBonferroni tests were used to compare more than two groups of quantitative variables that did not show normal distribution. The statistical significance was accepted as $p<0.05$. Relationships between numerical variables were examined with the Pearson Correlation Coefficient. Dunn's test was performed to make pairwise comparisons. P-values of $<0.05$ were considered statistically significant.

\section{RESULTS}

\section{Characteristics of the Sample}

A total of 557 healthcare professionals, wherein 204 (36.6\%) were male and 353 (63.4\%) were female, participated in the study. Among the participants $26.9 \%(n=150)$ were specialist doctor, $13.6 \%(n=76)$ were resident doctor, $17.4 \%(n=97)$ were nurse, $16.5 \%(n=92)$ were medical secretary, $14.7 \%$ $(n=82)$ were caregiver, and $10.8 \%(n=60)$ were security guard. Majority of them was working in outpatient $(37.7 \% ; n=210)$ and inpatients clinics $(30.9 \% ; n=172)$, whereas the rest was working in emergency $(16.0 \% ; n=89)$ and ICU $(15.4 \% ; n=86)$.

\section{Attitudes and COVID-19-related Knowledge of Participants}

Among the participants, $67.1 \%(n=374)$ had the COVID-19 test and $43.8 \% \quad(n=244)$ had the thoracic computerized tomography examination at least once since the pandemic began. The test result was positive in $20.9 \%(n=78)$ of those who had the COVID-19 polymerase chain reaction (PCR) test. Sufficient protection for themselves against the COVID-19 infection was thought to be provided by their institutions in $39.9 \%$ of participants. The attitudes and COVID-19-related knowledge of Participants' are presented in Table 1.

\section{Gender Differences in Scale Scores}

Evaluation of gender differences in scale scores revealed that females had higher levels of HADS-anxiety ( $p=0.001$; $p<0.01), \quad F C-19 S \quad(p=0.001 ; \quad p<0.01), \quad M B I$-emotional exhaustion ( $p=0.001 ; p<0.01)$, MSPSS-friend $(p=0.018$; $p<0.05)$, and MSPSS-significant other subscale $(p=0.017$; $p<0.05$ ) than males (Figure 1).
Table 1. Attitudes and COVID-19-related knowledge of participants

\begin{tabular}{lll}
\hline \multirow{2}{*}{$\begin{array}{l}\text { Keeping track of new literature } \\
\text { knowledge about COVID-19 }\end{array}$} & Yes & $503(90.3)$ \\
\cline { 2 - 3 } COVID-19 PCR examination & No & $54(9.7)$ \\
\cline { 2 - 3 } & Yes & $374(67.1)$ \\
\hline \multirow{2}{*}{ Thoracic CT examination } & Yes & $244(43.8)$ \\
\hline \multirow{2}{*}{$\begin{array}{l}\text { COVID-19 test result } \\
\text { Thinking that hospital } \\
\text { management provide adequate } \\
\text { COVID-19 protection methods for }\end{array}$} & Positive & $313(56.2)$ \\
\cline { 2 - 3 } him/herself & No not agree & $29(5.2)$ \\
\cline { 2 - 3 } & Partially agree & $306(54.9)$ \\
\hline $\begin{array}{l}\text { Thinking that the pandemic will } \\
\text { end }\end{array}$ & Agree & $296(79.1)$ \\
\cline { 2 - 3 } & Do not agree & $247(44.3)$ \\
\hline
\end{tabular}

COVID-19: Coronavirus disease-2019, CT: Computerized tomography, PCR: Polymerase chain reaction

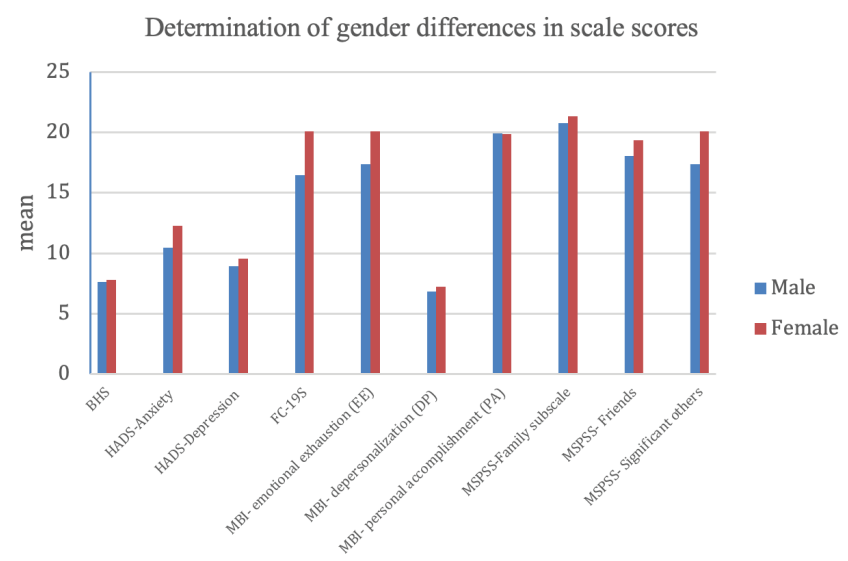

Figure 1. Determination of gender differences in scale scores

\section{Occupational Differences in Scale Scores}

The Kruskal-Wallis test and One-Way ANOVA analysis were performed to differentiate the variables into occupational groups, and results were reported in Table 2. No gender difference was found in the FC-19S scores. The BHS scores were significantly higher in resident doctors $(m d n=8)$ and caregivers $(m d n=10)$ compared to other occupational groups $[H \quad(5)=45,583, p<0.001]$. The HADS-anxiety scores were significantly higher in resident doctors [F $(5,5511)=3,072, p=0.011$ land the HADS-depression scores were higher in caregiver $[F(5,551)=4,557, p<0.001]$ than the others. The MBI-emotional Exhaustion $[F(5,551)=10.094$, $p<0.001]$ and MBI-Depersonalization $[H \quad(5)=29,190$, $p<0.001]$ scores were highest in the resident doctors than others. The MBI-personal accomplishment scores 

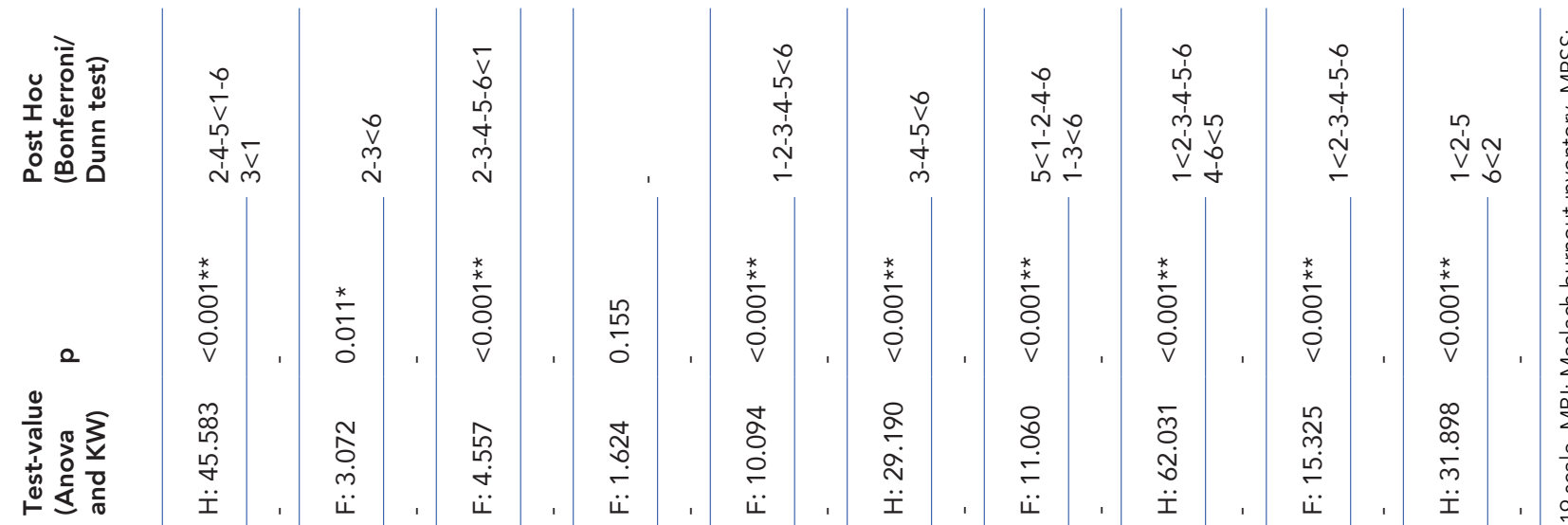

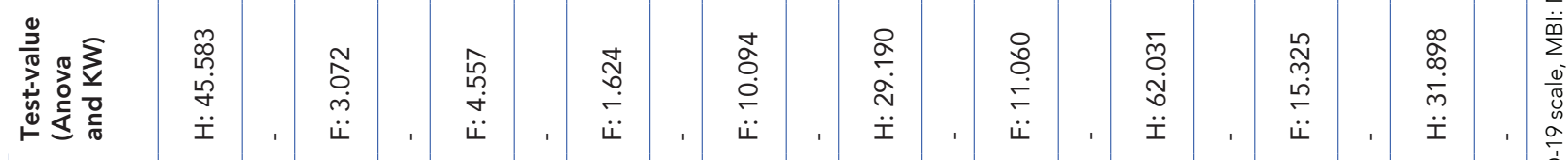

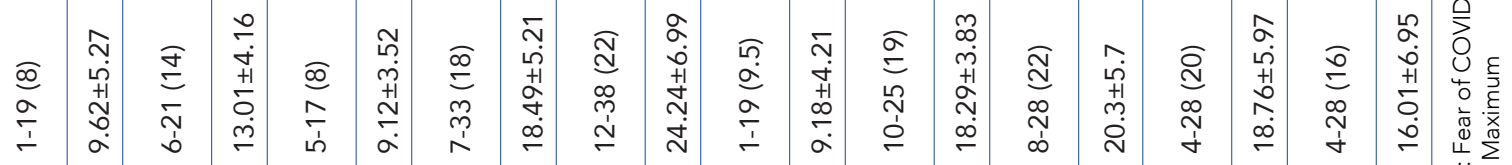

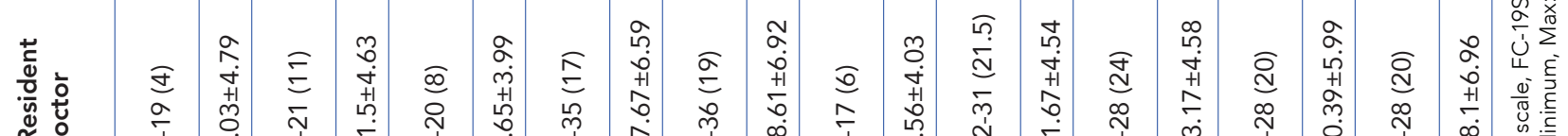



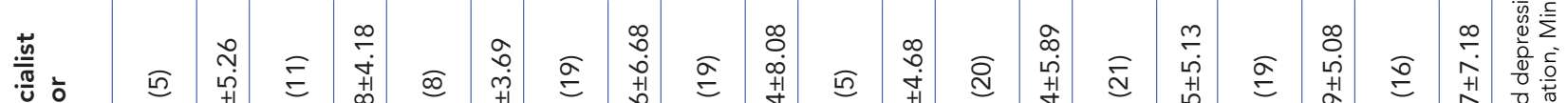



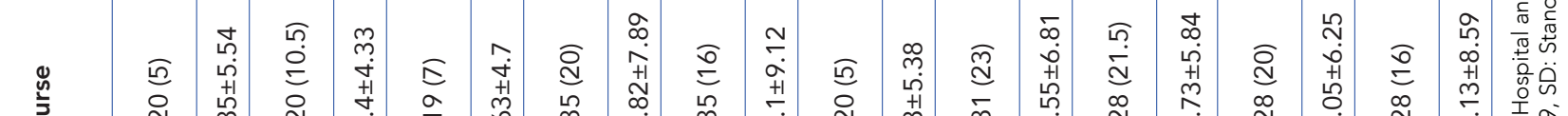

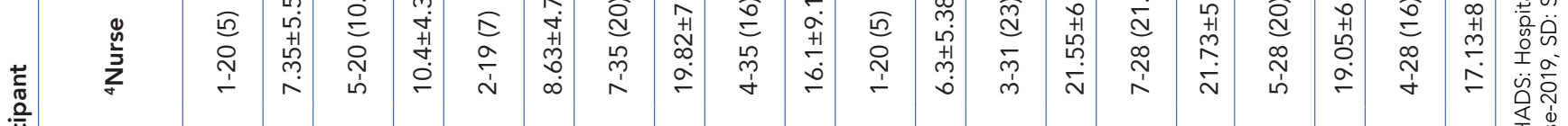

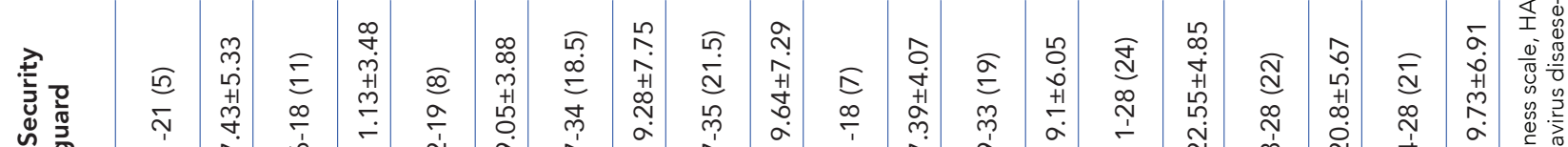

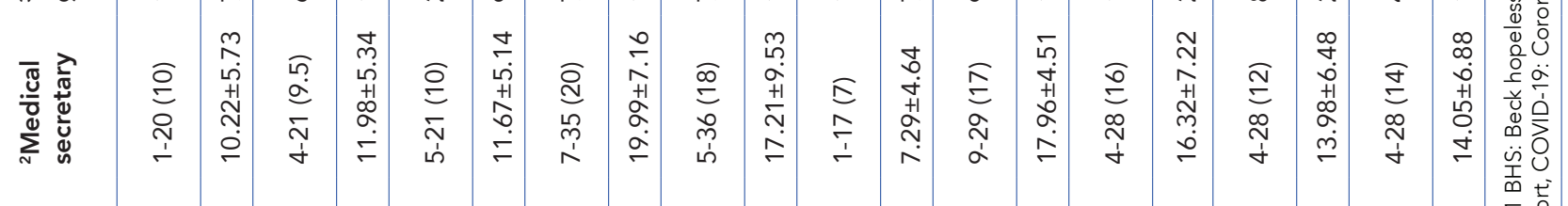

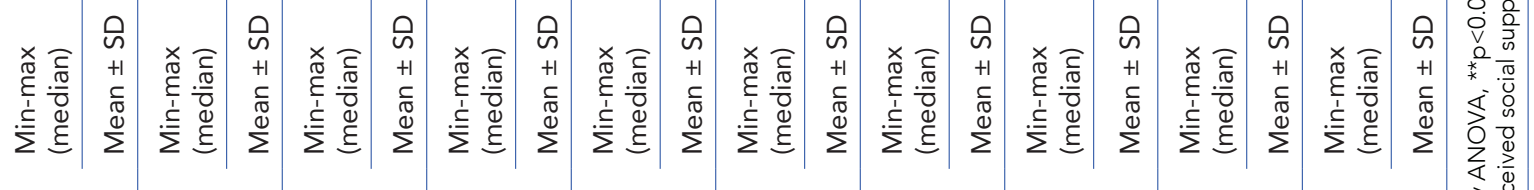

were statistically significantly higher in specialist doctors $(m d n=21.5)$ and security guards $(m d n=23)$ compared to others $[F(5,551)=11.060, p<0.001]$. The MSPSS-family scores were significantly higher in specialist doctors compared to nurses and resident doctors $[H(5)=62,031, p<0.001]$.

\section{Hospital Unit Differences in Scale Scores}

The Kruskal-Wallis test and One-Way ANOVA analysis were performed to determine the hospital unit differences in scale scores, and results were presented in Table 3. Compared to those working in other hospital units, participants working at ICU had significantly higher scores of HADS-depression [F $(3,553)=6,759, p=0.001], F C-19 S[F(3,553)=8,961, p<0.001]$ and $\mathrm{MBI}$-emotional exhaustion $[\mathrm{F}(3,553)=5,690, p<0.001]$. Compared to those working in inpatient clinics, participants working in outpatient clinics had significantly higher scores of MBI-personal accomplishment $[\mathrm{F}(3,553)=5,881, \mathrm{p}<0.001]$ and MSPSS-family $[H(3)=15,729, p<0.001]$ and MSPSSfriends $[F(3,553)=6,828, \quad p<0.001]$. No difference was found in the hospital unit in the BHS, HADS-anxiety, MBIdepersonalization, and MSPSS-significant other scores.

\section{Relationship Between Scale Scores and COVID-19 PCR Testing Status Among Participants}

Participants were examined in 2 groups, as those who had the COVID-19 PCR test and those who did not, and the scale scores of these two groups were compared. The MannWhitney and Student's t-tests were applied in statistics and results are shown in Table 4. Those who had the COVID-19 $\mathrm{PCR}$ test $(\mathrm{mdn}=6)$ had a significantly higher BHS score $(\mathrm{z}=-$ 3.123, $p=0.002)$ than those who did not $(m d n=5)$. Scores of HADS-anxiety ( $t=3.024, p=0.003)$, HADS-depression $(t=3.382, p=0.001)$, and $F C-19 S(t=3.022, p=0.003)$ were higher among those who had COVID-19 PCR test than those who did not, and the MSPSS-friend average scores were low. The MSPSS-Significant score value was lower in those who had the COVID-19 PCR test $(m d n=17.5)$ than those who did not $(m d n=20)(z=-2.222, p=0.026)$.

Table 3. Determination of hospital unit differences in scale scores

\begin{tabular}{|c|c|c|c|c|c|c|c|c|}
\hline \multirow[b]{2}{*}{${ }^{1}$ Out-patient clinic } & & \multicolumn{4}{|l|}{ Hospital Unit } & \multirow{2}{*}{$\begin{array}{l}\text { Testr value } \\
\text { (Anova and } \\
\mathrm{KW} \text { ) }\end{array}$} & \multirow[b]{2}{*}{$p$} & \multirow{2}{*}{$\begin{array}{l}\text { Post Hoc } \\
\text { (Bonferroni/ } \\
\text { Dunn test) }\end{array}$} \\
\hline & & $\begin{array}{l}{ }^{2} \text { Emergency } \\
\text { unit }\end{array}$ & $\begin{array}{l}\text { 3npatient } \\
\text { clinic }\end{array}$ & ${ }^{4} \mathrm{ICU}$ & & & & \\
\hline \multirow{2}{*}{$\mathrm{BHS}^{\mathrm{c}}$} & Min-max (median) & $1-21(5)$ & $1-20(6)$ & $1-20(6)$ & $1-19$ (9) & $\mathrm{H}: 6.807$ & 0.078 & - \\
\hline & Mean \pm SD & $7.22 \pm 5.47$ & $7.69 \pm 5.25$ & $7.65 \pm 5.26$ & $9.16 \pm 5.75$ & - & - & - \\
\hline \multirow{2}{*}{ HADS-anxiety ${ }^{d}$} & Min-max (median) & $5-21(11)$ & $5-20(10)$ & $4-21(11)$ & 4-21 (11.5) & F: 1.189 & 0.313 & - \\
\hline & Mean \pm SD & $11.67 \pm 4.4$ & $11.7 \pm 4.72$ & $11.14 \pm 4.3$ & $12.21 \pm 4.51$ & - & - & - \\
\hline \multirow{2}{*}{$\begin{array}{l}\text { HADS- } \\
\text { depression }^{d}\end{array}$} & Min-max (median) & $4-20(8)$ & $2-19(8)$ & $2-19(8)$ & $5-21(9)$ & F: 6.759 & $<0.001 \star \star$ & \multirow{2}{*}{$1-2-3<4$} \\
\hline & Mean \pm SD & $8.75 \pm 3.74$ & $9.39 \pm 4.4$ & $8.99 \pm 3.86$ & $11.5 \pm 5.22$ & - & - & \\
\hline \multirow{2}{*}{ FC-19Sd } & Min-max (median) & $7-33(18)$ & $7-33(16)$ & $7-35(17)$ & $7-35(21)$ & F: 8.961 & $<0.001^{\star \star}$ & $1-2-3<4$ \\
\hline & Mean \pm SD & $18.93 \pm 6.72$ & $17.67 \pm 7.14$ & $17.56 \pm 6.58$ & $21.94 \pm 6.81$ & - & - & - \\
\hline \multirow{2}{*}{$\begin{array}{l}\text { MBI-emotional } \\
\text { exhaustion }^{d}\end{array}$} & Min-max (median) & 4-38 (19) & $5-36(19)$ & $5-36(18)$ & 6-37 (21) & F: 5.690 & $<0.001^{\star \star}$ & $1-2-3<4$ \\
\hline & Mean \pm SD & $19.21 \pm 7.73$ & $18 \pm 8.96$ & $18.04 \pm 7.7$ & $22.16 \pm 8.59$ & - & - & - \\
\hline \multirow{2}{*}{$\begin{array}{l}\text { MBI- } \\
\text { depersonalization }\end{array}$} & Min-max (median) & $1-20(6)$ & $1-18(7)$ & $1-19(7)$ & $1-17(7)$ & H: 0.289 & 0.962 & - \\
\hline & Mean \pm SD & $7.2 \pm 4.61$ & $6.87 \pm 4.44$ & $7.16 \pm 4.55$ & $6.9 \pm 4.32$ & - & - & - \\
\hline \multirow{2}{*}{$\begin{array}{l}\text { MBI-personal } \\
\text { accomplishment }^{d}\end{array}$} & Min-max (median) & $3-30(21)$ & $8-33(20)$ & 8-31 (19) & $9-28(18.5)$ & F: 5.881 & $<0.001^{\star *}$ & $3-4<1$ \\
\hline & Mean \pm SD & $20.98 \pm 5.48$ & $20.06 \pm 5.51$ & $19.03 \pm 5.23$ & $18.65 \pm 5.19$ & - & - & - \\
\hline \multirow{2}{*}{$\begin{array}{l}\text { MSPSS-family } \\
\text { subscalec }^{c}\end{array}$} & Min-max (median) & $8-28(23)$ & $4-28(20)$ & $4-28(21)$ & $4-28(21)$ & $\mathrm{H}: 15.729$ & $<0.001^{\star \star}$ & $2-3-4<1$ \\
\hline & Mean \pm SD & $22.46 \pm 4.9$ & $20.33 \pm 5.97$ & $20.53 \pm 6.4$ & $19.77 \pm 6.36$ & - & - & - \\
\hline \multirow{2}{*}{ MSPSS-friends ${ }^{d}$} & Min-max (median) & 6--28 (20) & $5-28(19)$ & $4-28(18)$ & $4-28(17)$ & $F: 6.828$ & $<0.001 \star \star$ & $3-4<1$ \\
\hline & Mean \pm SD & $20.19 \pm 6.06$ & $18.54 \pm 6.07$ & $18.4 \pm 6.17$ & $16.81 \pm 6.48$ & - & - & - \\
\hline \multirow{2}{*}{$\begin{array}{l}\text { MSPSS-significant } \\
\text { others }^{c}\end{array}$} & Min-max (median) & 4-28 (19.5) & $4-28(20)$ & $4-28(17.5)$ & $4-28(17)$ & $\mathrm{H}: 3.722$ & 0.293 & - \\
\hline & Mean \pm SD & $17.79 \pm 7.41$ & $17.25 \pm 8.11$ & $16.9 \pm 6.94$ & $16.35 \pm 7.14$ & - & - & - \\
\hline
\end{tabular}


Akyüz Karacan et al. Psychosocial-Adjustment of Healthcare-Professionals in COVID-19 Pandemic

Table 4. Relationship between the scale scores and COVID-19-PCR testing status among participants

\begin{tabular}{|c|c|c|c|c|c|}
\hline \multirow[t]{2}{*}{ YES } & & \multicolumn{2}{|c|}{$\begin{array}{l}\text { Did the participant have COVID- } \\
19 \text { PCR test until now }\end{array}$} & \multirow{2}{*}{$\begin{array}{l}\text { Test value } \\
\text { (U) }\end{array}$} & \multirow{2}{*}{$p$} \\
\hline & & NO & & & \\
\hline \multirow{2}{*}{$\mathrm{BHS}^{\mathrm{a}}$} & Min-max (median) & $1-21(6)$ & $1-17(5)$ & z: -3.123 & $0.002^{\star \star}$ \\
\hline & Mean \pm SD & $8.29 \pm 5.7$ & $6.57 \pm 4.68$ & - & - \\
\hline \multirow{2}{*}{ HADS-anxiety ${ }^{b}$} & Min-max (median) & $4-21(12)$ & $5-21(10)$ & t: 3.024 & $0.003^{\star *}$ \\
\hline & Mean \pm SD & $11.96 \pm 4.71$ & $10.85 \pm 3.73$ & - & - \\
\hline \multirow{2}{*}{ HADS-depression ${ }^{b}$} & Min-max (median) & 2-21 (9) & $2-20(8)$ & t: 3.382 & $<0.001^{\star *}$ \\
\hline & Mean \pm SD & $9.74 \pm 4.47$ & $8.55 \pm 3.6$ & - & - \\
\hline \multirow{2}{*}{ FC-19Sb } & Min-max (median) & 7-35 (19) & 7-31 (17) & t: 3.022 & $0.003^{\star \star}$ \\
\hline & Mean \pm SD & $19.34 \pm 7.37$ & $17.62 \pm 5.68$ & - & - \\
\hline \multirow{2}{*}{ MBI-emotional exhaustion ${ }^{b}$} & Min-max (median) & 4-37 (19) & $5-38(19)$ & $\mathrm{t}:-0.360$ & 0.719 \\
\hline & Mean \pm SD & $19.02 \pm 8.37$ & $19.29 \pm 7.76$ & - & - \\
\hline \multirow{2}{*}{ MBI-depersonalization ${ }^{a}$} & Min-max (median) & $1-20(7)$ & $1-18(6)$ & z: -0.469 & 0.639 \\
\hline & Mean \pm SD & $7.11 \pm 4.42$ & $7.05 \pm 4.7$ & - & - \\
\hline \multirow{2}{*}{ MBI-personal accomplishment ${ }^{b}$} & Min-max (median) & $8-33(20)$ & $3-31(20)$ & t: -0.475 & 0.635 \\
\hline & Mean \pm SD & $19.79 \pm 5.25$ & $20.03 \pm 5.81$ & - & - \\
\hline \multirow{2}{*}{ MSPSS-familya } & Min-max (median) & $4-28(22)$ & $8-28(22)$ & $z:-1.565$ & 0.118 \\
\hline & Mean \pm SD & $20.76 \pm 6.16$ & $21.81 \pm 5.22$ & - & - \\
\hline \multirow{2}{*}{ MSPSS-friends ${ }^{b}$} & Min-max (median) & $4-28(19)$ & $8-28(20)$ & t: -3.216 & $<0.001 * *$ \\
\hline & Mean \pm SD & $18.26 \pm 6.47$ & $20.06 \pm 5.63$ & - & - \\
\hline \multirow{2}{*}{ MSPSS-significant others ${ }^{a}$} & Min-max (median) & $4-28(17.5)$ & $4-28(20)$ & z: -2.222 & $0.026^{\star}$ \\
\hline & Mean \pm SD & $16.73 \pm 7.42$ & $18.18 \pm 7.09$ & - & - \\
\hline $\begin{array}{l}\text { aMann-Whitney U test, bStudent's t-te } \\
19 \text { scale, MBI: Maslach burnout Inven } \\
\text { chain reaction, SD: Standart deviation }\end{array}$ & $\begin{array}{l}\text { 5, }{ }^{\star *} p<0.01, \text { BHS: Beck } \\
\text { : Multidimensional sca } \\
\text { imum, Max: Maximum }\end{array}$ & $\begin{array}{l}\text { ss scale, HADS: } \\
\text { ed social suppo }\end{array}$ & $\begin{array}{l}\text { tal anxiety and depr } \\
\text { VID-19: Coronavirus }\end{array}$ & $\begin{array}{l}\text { sion scale FC-1 } \\
\text { sease-2019, PC }\end{array}$ & $\begin{array}{l}\text { Fear of COV } \\
\text { Polymerase }\end{array}$ \\
\hline
\end{tabular}

\section{Comparisons of Social Support Subscale (MSPSS) Scores With Other Scale Scores}

The Pearson correlation analysis was applied to determine the relationship between the MSPSS scores and other scale scores, and the results are shown in Table 5. Negative correlations were found between the scores of BHS and each MSPSS subscales [Family ( $r=-0.397)$, Friend $(r=-0.366)$ and Significant other $(r=-0.369)$ ] (for all $p<0.01)$. In addition, the MSPSS (family, friend, and significant other) scores were negatively correlated with HADS-anxiety, HADS-depression, and MBI-emotional exhaustion ( $p<0.01)$. A statistically significant negative correlation was found between the MSPSS-friend and FC-19S scores ( $r=-0.167, p<0.01)$. Moreover, the MSPSS (family, friend, and significant other) scores positively correlated with $\mathrm{MBI}$ - depersonalization $(r=0.228, r=0.207$, and $r=0.242$, respectively) (for all, $p<0.01$ ).

\section{DISCUSSION}

Many people suffered a severe illness course or died due to COVID-19 infection. Many experienced severe illnesses or the death of loved ones. In addition, people were exposed to economical, daily life, educational, and occupational changes. Many governments applied rules for social isolation to both sick and healthy individuals to prevent the spread of the disease. The time to return to previous normals is unknown. All these may lead to increased distress in an individual's life. Recent studies have demonstrated that the COVID-19 pandemic leads to distress and negative outcomes on the psychosocial well-being of the general population. Health workers are also part of society. Moreover, they have to work with patients with COVID-19 due to their professions, which makes it inevitable for them to be affected by the pandemic process. Healthcare professionals carry increased risk not only in physical but also mental health 
Table 5. Comparisons of social support subscale scores with other scale scores

\begin{tabular}{|c|c|c|c|c|}
\hline & & $\begin{array}{l}\text { MSPSS- } \\
\text { family } \\
\text { subscale }\end{array}$ & $\begin{array}{l}\text { MSPSS- } \\
\text { friends } \\
\text { subscale }\end{array}$ & $\begin{array}{l}\text { MSPSS- } \\
\text { significant } \\
\text { others } \\
\text { subscale }\end{array}$ \\
\hline \multirow{2}{*}{$\mathrm{BHS}$} & $r$ & $-0.397 * \star$ & $-0.366^{\star \star}$ & $-0.369 * \star$ \\
\hline & $\mathrm{n}$ & 557 & 557 & 557 \\
\hline \multirow{2}{*}{ HAD-A } & r & $-0.235^{\star \star}$ & $-0.214^{\star \star}$ & $-0.194^{\star \star}$ \\
\hline & $\mathrm{n}$ & 557 & 557 & 557 \\
\hline \multirow{2}{*}{ HAD-D } & $r$ & $-0.340^{\star \star}$ & $-0.316^{\star \star}$ & $-0.345^{\star \star}$ \\
\hline & $\mathrm{n}$ & 557 & 557 & 557 \\
\hline \multirow{2}{*}{ FC-19S } & $r$ & $-0.108^{*}$ & $-0.167^{\star \star}$ & $-0.085^{\star}$ \\
\hline & $\mathrm{n}$ & 557 & 557 & 557 \\
\hline \multirow{2}{*}{$\begin{array}{l}\text { MBI-emotional } \\
\text { exhaustion }\end{array}$} & $r$ & $-0.110^{\star \star}$ & $-0.168^{\star \star}$ & $-0.150 \star \star$ \\
\hline & $\mathrm{n}$ & 557 & 557 & 557 \\
\hline \multirow{2}{*}{ MBI-depersonalization } & r & $-0.182^{\star \star}$ & $-0.198 * \star$ & $-0.202^{\star \star}$ \\
\hline & $\mathrm{n}$ & 557 & 557 & 557 \\
\hline $\begin{array}{l}\text { MBI-personal } \\
\text { accomplishment }\end{array}$ & $r$ & $0.228 * \star$ & $0.207^{\star \star \star}$ & $0.242^{\star \star}$ \\
\hline
\end{tabular}

BHS: Beck hopelessness scale, HADS: Hospital anxiety and depression scale, FC-19S: Fear of COVID-19 scale, MBI: Maslach burnout inventory, MPSS: Multidimensional scale of perceived social support

because they work in the frontline during the pandemic $(4,7,9)$. Psychosocial adjustment to a specific stressor is related to the characteristics and social environment of the individual. Therefore, people are not equally influenced by stressor exposure during the pandemic. This study aimed to examine the psychosocial adjustment and its individual and environmental correlation in healthcare professionals who worked in pandemic hospitals from the beginning of the pandemic. That is, we examined the healthcare professionals who worked at the frontline during this pandemic and found that their psychological well-being was related to their gender, occupation, and the hospital unit where they worked during the pandemic. Moreover, social support, COVID-19 attitude, and psychosocial adjustment were interrelated with each other.

Studies have shown that during the COVID-19 pandemic, the psychosocial adjustment of the healthcare professionals is affected by gender, and females have higher anxiety, depression, and distress levels than males $(11,12,26)$. In addition, a systematic review and meta-analysis study in this group have found that the pooled anxiety prevalence was $29.06 \%$ in females and $20.92 \%$ in males (27). This current study found higher levels of anxiety, COVID-19 fear, emotional exhaustion, and social support in female healthcare professionals compared to male counterparts.
The female gender is well-known to be associated with an increased risk for anxiety disorders and is more vulnerable than males in the presence of stress (28). Our gender-related result supports the literature knowledge.

Examination of participants according to their occupational groups and hospital units showed that psychological health was most dramatically affected in assistant doctors, caregivers, and those working in the ICU. The highest levels of anxiety, hopelessness, emotional exhaustion and depersonalization were seen in assistant doctors, and the highest depression scores were seen in caregivers. Contrarily, the highest personal success scores were seen in specialist doctors and security guards. Working in the ICU was associated with increased depression, fear of COVID-19, and emotional exhaustion, whereas working in the outpatient clinic was associated with increased personal success scores. All these findings indicate that closer and frequent contact with patients with COVID-19 causes increased negative psychological outcomes in healthcare professionals. In pandemic hospitals, resident doctors and caregivers and healthcare professionals in ICU worked in close contact with longer durations. Moreover, the healthcare professionals in the ICU had to experience their colleagues' serious illness course and death due to COVID-19. While all these are already difficult and troublesome, when the unknowns about the COVID-19 pandemic are considered, it may lead to an increased psychological burden on these healthcare professionals, especially those working in the ICU.

Frontline healthcare professionals could be more accustomed to potentially distressing experiences than non-frontline professionals, thus showing a lower negative response to challenging situations $(12,14)$. However, studies have shown that nurses and those who work in the frontline with close contact with patients and those who work for long hours have more frequent negative psychological outcomes among the healthcare professionals during the COVID-19 pandemic (4). Moreover, these studies were conducted in the acute phase of the pandemic and included only specific occupational groups. Contrarily, this current study included all hospital staff working in COVID-19 pandemic hospitals serving patients with COVID-19 only. All participants were the frontline healthcare professionals since they worked in a pandemic hospital. Therefore, we think that our study predicts the relationship of psychosocial adjustment with the hospital unit and occupational groups in frontline healthcare professionals better than the previous studies.

The World Health Organization and the scientific world emphasize the importance of prevention methods for 
the disease spread in the general population and health care professionals from the beginning of the pandemic. Special equipment and working hours arrangements were recommended for healthcare professionals. However, particularly at the beginning of the pandemic, as in many other countries, adequate equipment was not provided in many health institutions in Turkey, and medical doctors in different specialties had to work in COVID-19 outpatient and inpatients clinics with long working hours. Thus, we thought that frequent and unexpected changes in workplaces might lead to anxiety, hopelessness, and burnout in healthcare professionals.

This study examined the COVID-19 knowledge and attitudes of healthcare professionals. A majority reported that they were following new literature on COVID-19 and believed that the pandemic would end. In addition, a majority reported the insufficient provision of protection for COVID-19 infection from their institution. An inverse relation was demonstrated between the COVID-19 attitude and psychological adjustment in the healthcare professionals. In healthcare professionals, insufficient protection from COVID-19 means increased risk not only for getting sick but also for carrying the disease to their families. These thoughts lead to further social isolation within the family. All these factors were thought to increase the psychological burden on healthcare professionals and result in negative psychological outcomes. Similar studies emphasize that healthcare professionals are concerned about the protection or safety of themselves and their families from the disease, which is also another important stress factor (29). Trumella et al. (14) also state that a negative COVID-19 attitude can affect healthcare professionals mentally and even negatively affect their work performance.

Social support is one of the most important resources to cope with the psychological burden following the pandemic (29). Social support given to medical staff reduced anxiety and stress levels and increased their self-efficacy. Keeping stable working teams, improving communication and recognition, and providing clear guidelines and social support are examples of how the working environment could be improved during the pandemic $(4,30)$.

Our study findings showed a negative relationship between social support and anxiety, depression, emotional exhaustion, depersonalization, and fear of COVID-19. COVID-19 attitude was more negative in those with low social support. Social support differed in occupational groups. Caregivers, resident doctors, and nurses had lower social support than others. The highest social support was seen in specialist doctors and outpatient clinic staff.
Our study results pointed out that the psychological adjustment and COVID-19 attitude of healthcare professionals working at the frontline during the COVID-19 pandemic were negatively affected, especially in those with lower social support. In addition, higher social support was associated with personal achievement. These findings were consistent with the literature. Our most striking finding related to social support was that healthcare professionals who work closely and have frequent contact with patients with COVID-19 had lower social support. These healthcare professionals themselves may be avoiding social contact because of their higher disease-carrying risk. Moreover, they may be isolated by their social environment and even by their family member. Especially in the first months of the pandemic, when the news in media warned many people in the society to stay away from healthcare professionals and healthcare professionals are labeled as contagious.

\section{Study Limitations}

The major limitation of this study was its cross sectionality. Another limitation is the sample. The subgroups of the sample had different educational levels with probable different socio-cultural and economic levels. In addition, this study was carried out on only one side of Istanbul and did not include the health care professionals from rural areas of the same city or country. However, the risk of transmission and lack of resources remains a common problem in healthcare facilities all around the country and future research needs to examine the experiences of healthcare workers within the rural hospitals as well.

\section{CONCLUSION}

This study evaluated the psychosocial adaptation of the healthcare professionals in a multidimensional approach, considering many areas, including depression, general anxiety, phobic anxiety specifically towards the COVID-19 disease, and hopelessness. Consistent with the literature, results showed that healthcare professionals were negatively affected by the COVID-19 pandemic process in terms of psychosocial adjustment. In addition, study results indicate that gender, occupation, and hospital unit are important factors for psychosocial adjustment during the pandemic. Moreover, psychosocial adjustment showed to be related to social support and the COVID-19 attitude of the healthcare professionals. Today, the COVID-19 pandemic continues. In the long run, the life quality and functionality of healthcare professionals should be considered. Our study results indicated that healthcare professionals who have high contact with patients with COVID-19 have high anxiety for themselves and their families. Therefore, planning for 
psychosocial support programs and providing psychiatrist or psychologist assistance at regular intervals is thought to be important for healthcare workers. In addition, social support can be provided to health workers through institutions, associations, and professional organizations. Considering that the pandemic process will continue and new or different pandemic processes may emerge, providing adequate protective equipment against the specific infectious disease, providing adequate rest periods, and determining a regular job and place for health workers in the frontlines during the epidemics will have a more functional result in their psychosocial adjustment and professional lives. This study revealed the healthcare professionals that have increased risk for psychosocial adjustment problems, study results are valuable for both healthcare professionals and hospital managers, as well as the governments.

\section{Acknowledgments}

The authors would like to thank all the participants who kindly agreed to participate in the study.

\section{ETHICS}

Ethics Committee Approval: This study was conducted according to the provisions of the Declaration of Helsinki in 1995. Approval was obtained from the Ethics Committee of the same hospital with the University of Health Sciences Turkey, Bakirköy Dr. Sadi Konuk Training and Research Hospital (protocol number: 2020-157).

Informed Consent: Written and verbal consent of each participant was obtained.

\section{Authorship Contributions}

Surgical and Medical Practices: F.A.K., Concept: F.A.K., S.Y., Design: F.A.K., I.K., Data Collection or Processing: F.A.K., S.Y., i.K., Analysis or Interpretation: F.A.K., S.Y., I.K., Literature Search: F.A.K., S.Y., Writing: F.A.K., S.Y.

Conflict of Interest: No conflict of interest was declared by the authors.

Financial Disclosure: The authors declared that this study received no financial support.

\section{REFERENCES}

1. Porta M. A Dictionary of Epidemiology. 6th edit. Oxford university press; New York: 2014.

2. Republic of Turkey Ministry of Health, 2021. Covid-19 information page. https://covid19.saglik.gov.tr/EN-69532/general-coronavirustable.html. Accessed on 8.5.2021

3. Banerjee D, Rai M. Social isolation in Covid-19: The impact of loneliness. Int J Soc Psychiatry 2020;66:525-7.

4. Zerbini G, Ebigbo A, Reicherts P, Kunz M, Messman H. Psychosocial burden of healthcare professionals in times of COVID-19 - a survey conducted at the University Hospital Augsburg. Ger Med Sci 2020;18:Doc05.

5. Hacimusalar $Y$, Kahve AC, Yasar AB, Aydin MS. Anxiety and hopelessness levels in COVID-19 pandemic: A comparative study of healthcare professionals and other community sample in Turkey. J Psychiatr Res 2020;129:181-8.

6. Gica S, Kavakli M, Durduran Y, Ak M. The Effect of COVID-19 Pandemic on Psychosomatic Complaints and Investigation of The Mediating Role of Intolerance to Uncertainty, Biological Rhythm Changes and Perceived COVID-19 Threat in this Relationship: A Web-Based Community Survey. Psychiatry and Clinical Psychopharmacology 2020;30:89-96.

7. Cullen W, Gulati G, Kelly BD. Mental health in the COVID-19 pandemic. QJM 2020;113:311-2.

8. Shah K, Chaudhari G, Kamrai D, Lail A, Patel RS. How Essential Is to Focus on Physician's Health and Burnout in Coronavirus (COVID-19) Pandemic? Cureus 2020;12:e7538.

9. Kisely S, Warren N, McMahon L, Dalais C, Henry I, Siskind D. Occurrence, prevention, and management of the psychological effects of emerging virus outbreaks on healthcare workers: rapid review and meta-analysis. BMJ 2020;369:m1642.

10. Spoorthy MS, Pratapa SK, Mahant S. Mental health problems faced by healthcare workers due to the COVID-19 pandemic-A review. Asian J Psychiatr 2020;51:102119.

11. Lai J, Ma S, Wang Y, Cai Z, Hu J, Wei N, et al. Factors Associated With Mental Health Outcomes Among Health Care Workers Exposed to Coronavirus Disease 2019. JAMA Netw Open 2020;3:e203976.

12. Kang L, Ma S, Chen M, Yang J, Wang Y, Li R, et al . Impact on mental health and perceptions of psychological care among medical and nursing staff in Wuhan during the 2019 novel coronavirus disease outbreak: A cross-sectional study. Brain Behav Immun 2020;87:117.

13. García-Reyna B, Castillo-García GD, Barbosa-Camacho FJ, Cervantes-Cardona GA, Cervantes-Pérez E, Torres-Mendoza BM, et al. Fear of COVID-19 Scale for Hospital Staff in Regional Hospitals in Mexico: a Brief Report. Int J Ment Health Addict 2020:1-12.

14. Trumello C, Bramanti SM, Ballarotto G, Candelori C, Cerniglia L, Cimino $S$, et al. Psychological Adjustment of Healthcare Workers in Italy during the COVID-19 Pandemic: Differences in Stress, Anxiety, Depression, Burnout, Secondary Trauma, and Compassion Satisfaction between Frontline and Non-Frontline Professionals. Int J Environ Res Public Health 2020;17:8358.

15. Hu D, Kong Y, Li W, Han Q, Zhang X, Zhu LX, et al. Frontline nurses' burnout, anxiety, depression, and fear statuses and their associated factors during the COVID-19 outbreak in Wuhan, China: A largescale cross-sectional study. EClinicalMedicine 2020;24:100424.

16. Zigmond AS, Snaith RP. The hospital anxiety and depression scale. Acta Psychiatr Scand 1983;67:361-70.

17. Aydemir Ö, Güvenir T, Küey L, Kültür S. Reliability and Validity of the Turkish version of Hospital Anxiety and Depression Scale. Turkish journal of psychiatry 1997;8:280-7.

18. Beck AT, Weissman A, Lester D, Trexler L. The measurement of pessimism: the hopelessness scale. J Consult Clin Psychol 1974;42:861-5.

19. Durak A, Palabıyıkoğlu R. Beck Hopelessness Scale: reliability and validity. J Kriz 1994; 2:311-9.

20. Maslach V, Jackson SE. Maslach Burnout Inventory Manual. Palo Alto, CA: Consulting Psychologist Press; 1986.

21. Ergin $C$. Burnout in doctors and nurses, and adaptation of the maslach burnout scale. In Bayraktar R, Dağ I (eds): VII. National Psychology Congress Scientific Studies Turkish Psychological Association publishing; 1992. p. 143-54. 
22. Ahorsu DK, Lin CY, Imani V, Saffari M, Griffiths MD, Pakpour AH. The Fear of COVID-19 Scale: Development and Initial Validation. Int J Ment Health Addict 2020:1-9.

23. Ladikli N, Bahadır E, Yumuşak FN, Akkuzu H, Karaman G, Türkkan Z. The reliability and validity of Turkish version of coronavirus anxiety scale. International journal of social sciences 2020;3:71-80.

24. Zimet GD, Dahlem NW, Zimet SG, Farley GK. The multidimensional scale of perceived social support. J Pers Assess 1988;52:30-41.

25. Eker D, Arkar H, Yaldız H. Factorial Structure, Validity, and Reliability of the Multidimensional Scale of Perceived Social Support. Turkish journal of psychiatry 2001;12:17-25.

26. Yas Coskun S, Bildik F, Aslaner MA, Aslan S, Keles A, Kilicaslan I, et al. The Effect of the COVID-19 Pandemic on the Psychological Status of Hospital Workers. Psychiatry and Clinical Psychopharmacology 2020;30:264-72.
27. Pappa S, Ntella V, Giannakas T, Giannakoulis VG, Papoutsi E, Katsaounou P. Prevalence of depression, anxiety, and insomnia among healthcare workers during the COVID-19 pandemic: A systematic review and meta-analysis. Brain Behav Immun 2020;88:901-7.

28. Newman MG, Shin KE, Zuellig AR. Developmental risk factors in generalized anxiety disorder and panic disorder. J Affect Disord 2016;206:94-102.

29. Xiao H, Zhang Y, Kong D, Li S, Yang N. The Effects of Social Support on Sleep Quality of Medical Staff Treating Patients with Coronavirus Disease 2019 (COVID-19) in January and February 2020 in China. Med Sci Monit 2020;26:e923549.

30. Petzold MB, Plag J, Ströhle A. Umgang mit psychischer Belastung bei Gesundheitsfachkräften im Rahmen der COVID-19-Pandemie [Dealing with psychological distress by healthcare professionals during the COVID-19 pandemia]. Nervenarzt 2020;91:417-21. 